\title{
15. GEOCHEMISTRY OF SEDIMENTS FROM THE EAST PACIFIC RISE AT $23^{\circ} \mathbf{N}^{1}$
}

\author{
S. A. Moorby, A.G.R.G., Geology Department, Imperial College, London, United Kingdom \\ S. P. Varnavas, Department of Geology, University of Patras, Patras, Greece \\ and \\ D. S. Cronan, A.G.R.G., Geology Department, Imperial College, London, United Kingdom
}

\begin{abstract}
We looked for chemical evidence of hydrothermal activity in sediments from Leg 65 sites. All the sediments analyzed showed bulk compositions typical of normal hemipelagic sediments, and there was no evidence of Fe-enriched basal sediment of the type that is widespread elsewhere on the East Pacific Rise and rise flanks. No definite chemical evidence was found for the presence of hydrothermal sulfides similar to those forming nearby on the East Pacific Rise at $21^{\circ} \mathrm{N}$, but in view of the localized nature of the latter, deposits of this type cannot be ruled out in the area drilled by Leg 65.
\end{abstract}

\section{INTRODUCTION}

Metalliferous sediments have been known to be associated with the East Pacific Rise for some time (Böstrom and Peterson, 1966; Boström et al., 1969) and have been found immediately overlying the flanks of basement rocks in many localities (von der Borch and Rex, 1970; Sayles and Bischoff, 1973; Boström et al., 1976; Cronan, 1976). Sulfides of hydrothermal origin have been observed to be accumulating at the ridge crest at $21^{\circ} \mathrm{N}$ (Francheteau et al., 1979), but so far no ancient analogs of such sulfide deposits have been reported on the flanks of the East Pacific Rise. One of the aims of the present work was to seek such sulfides in the Leg 65 sediments.

\section{SEDIMENT DESCRIPTION}

We took a total of 104 samples from immediately above basement and throughout the sediment column at Sites $482,483,484$, and 485 . The sedimentary succession in all the holes consists mainly of hemipelagic silty clay with some minor nannofossil and radiolarian clays and minor interbedded turbidites.

\section{Site 482}

We analyzed sediments from Holes 482B, 482C, $482 \mathrm{D}$, and $482 \mathrm{~F}$. All are predominantly hemipelagic silty clays with some minor turbidites and calcareous oozes. This site is the closest to the present spreading center, and the basement is therefore the youngest in age of the four sites occupied during Leg 65 .

\section{Site $\mathbf{4 8 3}$}

We analyzed material from Holes 483, 483B, and 483C. Hemipelagic clays dominate the lithology at this site. In addition to sampling sediments immediately

\footnotetext{
${ }^{1}$ Lewis, B. T. R., Robinson, P., et al,, Init. Repts. DSDP, 65: Washington (U.S. Govt. Printing Office).
}

above the basement, a clayey siltstone from between the two uppermost flows within the basement was sampled in Holes 483 and 483B. Sedimentation at this site was slower than at the other Leg 65 sites (Lewis et al., 1979).

\section{Site $\mathbf{4 8 4}$}

Hemipelagic clays are the major sediment type at Site 484 but some minor turbidites also occur. The lithology generally indicates that this site, which is on a slight elevation in a transform valley, was isolated from much of the hemipelagic and terrigenous sedimentation found elsewhere in the valley.

\section{Site $\mathbf{4 8 5}$}

Sediments from Holes 485 and $485 \mathrm{~A}$ were analyzed. They are again mainly hemipelagic, but particularly toward the basement, there are some carbonate-rich layers, and turbidites are more common. Beneath the uppermost basalt flow, sediments consist predominantly of mudstones, and these were also sampled.

At all sites, small amounts of pyrite are present in the sediments. At Site 482 the pyrite increases near the sediment/basement contact. In Hole 485A small pyrite veins fill fissures in lithified sediments between the uppermost basalt flows. The presence of pyrite, plant debris (Site 485), the smell of $\mathrm{H}_{2} \mathrm{~S}$ (Site 485), and sediment coloration indicate that conditions within the sediments at all four sites were reducing below shallow depths.

\section{ANALYTICAL TECHNIQUES}

We prepared the sediments for analysis by freeze-drying and grinding them to a fine powder. Samples were analyzed for $\mathrm{Mn}, \mathrm{Fe}, \mathrm{Co}, \mathrm{Ni}$, $\mathrm{Cu}, \mathrm{Zn}, \mathrm{Pb}, \mathrm{Mg}, \mathrm{Ca}$, and $\mathrm{Al}$ on a Perkin-Elmer 403 atomic absorption spectrophotometer after dissolution in mixed hydrofluoric, nitric, and perchloric acids. Silicon was determined after a separate dissolution by hydrofluoric and hydrochloric acids in sealed bottles. The samples were also subjected to selective chemical attacks using an adaptation of the leach techniques developed by Chester and Hughes (1967) and described in detail by Cronan (1976). The leachates from each attack were analyzed for the same elements (except $\mathrm{Si}$ ) using the techniques described for bulk samples. 


\section{BULK COMPOSITION}

A summary of the results of the bulk chemical studies of the sediments is given in Table 1. Analytical precision was better than $\pm 10 \%$ on the basis of replicate analysis. Accuracy was checked against USGS rock and internal sediment standards. The average values of all the elements analyzed show little variation from hole to hole or site to site. The concentrations of most elements in the Leg 65 sediments are generally similar to those seen in hemipelagic sediments from the Pacific and elsewhere (Wright, 1972; Calvert, 1976). The average concentrations of $\mathrm{Mg}, \mathrm{Al}$, and $\mathrm{Si}$ are typical of sediments of silt to clay size from near-shore and hemipelagic environments (Wright, 1972), but the Ca values are somewhat higher, probably because of the presence of small amounts of biogenic $\mathrm{CaCO}_{3}$ (see Geochemical Partitioning). In many cases, calcium concentrations vary more with depth within single holes than between sites, the variations being due mainly to varying carbonate content. Overall, the calcium carbonate contents are low, only four samples containing substantially more than $5 \%$ $\mathrm{CaCO}_{3}$.

There is little variation in $\mathrm{Fe}, \mathrm{Mg}, \mathrm{Al}$, or $\mathrm{Si}$ values at the four sites, and $\mathrm{Co}$ and $\mathrm{Pb}$ also show little variation. $\mathrm{Mn}, \mathrm{Ni}, \mathrm{Cu}$, and $\mathrm{Zn}$, however, show an overall enrichment in all three holes at Site 483 , compared to values seen at the other sites. Manganese is also slightly enriched at Site 484, relative to values at the other sites.

In Hole 483, Mn, $\mathrm{Ni}, \mathrm{Cu}$, and $\mathrm{Zn}$ show enrichments throughout much of the sequence, whereas in Holes $483 \mathrm{~B}$ and $483 \mathrm{C}$ the enrichments occur over a very limited thickness range. At Holes 483 and 483B the basal sediment shows signs of slight enrichment in $\mathrm{Mn}, \mathrm{Fe}$, $\mathrm{Ni}, \mathrm{Cu}$, and $\mathrm{Zn}$ (Fig. 1), but no basal enrichment of these elements occurs in Hole $483 \mathrm{C}$ or indeed in any of the holes at the other three sites. In Hole 483 the basal sediment is significantly higher in $\mathrm{Mn}, \mathrm{Co}, \mathrm{Ni}, \mathrm{Cu}, \mathrm{Zn}$, and to some extent $\mathrm{Fe}$, as compared with sediments at other sites; this enrichment persists upward throughout the sediment column from near the basalt/sediment contact, although $\mathrm{Mn}$ values drop off markedly about 40 meters below the mudline. Sediments from beneath the uppermost basalt flow in Hole 483 show no such enrichments, being similar in composition to the nearsurface sediments. In fact, no metal enrichments occur in sediments from beneath the uppermost basalt flow in any of the holes.

Even the most metal-enriched sediments from Site 483 display levels of $\mathrm{Mn}, \mathrm{Fe}, \mathrm{Co}, \mathrm{Ni}, \mathrm{Cu}$, and $\mathrm{Zn}$ that are only intermediate between those found in hemipelagic sediments and those of typical surface Pacific pelagic clays (see Table 1). The high concentrations of these metals present in metalliferous sediments elsewhere on the East Pacific Rise were not approached in the sediments analyzed.

\section{GEOCHEMICAL PARTITIONING}

Chemical partitioning studies were carried out on 26 selected samples from various depths in all the holes studied in order to investigate the distribution of the elements between the constituent phases of the sediments. The results are presented in Table 2.

\section{Manganese}

Sediments from all four sites show little difference in the distribution of Mn between the four phases studied. Much of the $\mathrm{Mn}(50 \%)$ is $\mathrm{HCl}$-soluble and, therefore, probably associated with clays; most of the rest ( $30 \%$ of the total) is acetic acid-soluble. In one high-Mn, carbonate-rich sample, over $90 \%$ of the total Mn was acetic acid-soluble, indicating its presence as oxide coatings on biogenic carbonate material or perhaps by inclusion within the carbonate itself (Emiliani, 1955; Horder, 1979). However, in view of the low carbonate content of most of the samples, much of the acetic acid-soluble $\mathrm{Mn}$ may represent adsorbed species on clays. Less than $10 \%$ of the total $\mathrm{Mn}$, on average, is present in the hydroxyl-

Table 1. Average bulk composition of Leg 65 sediments.

\begin{tabular}{|c|c|c|c|c|c|c|c|c|c|c|c|c|}
\hline Hole & No. & $\begin{array}{c}\mathrm{Fe} \\
(\%)\end{array}$ & $\underset{(\mathrm{ppm})}{\mathrm{Mn}}$ & $\begin{array}{c}\text { Co } \\
\text { (ppm) }\end{array}$ & $\underset{(\mathrm{ppm})}{\mathrm{Ni}}$ & $\underset{(\mathrm{ppm})}{\mathrm{Cu}}$ & $\underset{(\mathrm{ppm})}{\mathrm{Zn}}$ & $\begin{array}{c}\mathrm{Pb} \\
(\mathrm{ppm})\end{array}$ & $\begin{array}{l}\mathrm{Mg} \\
(\%)\end{array}$ & $\begin{array}{c}\mathrm{Ca} \\
(\%)\end{array}$ & $\begin{array}{c}\mathrm{Al} \\
(\%)\end{array}$ & $\underset{(\%)}{\mathrm{Si}}$ \\
\hline $482 \mathrm{~B}$ & 10 & 3.0 & 490 & 42 & 62 & 38 & 144 & 47 & 1.27 & 2.1 & 6.9 & 23.6 \\
\hline $482 \mathrm{C}$ & 5 & 3.0 & 480 & 38 & 63 & 39 & 155 & 53 & 1.37 & 2.1 & 6.8 & 24.3 \\
\hline 482D & 7 & 3.1 & 430 & 43 & 72 & 50 & 150 & 48 & 1.20 & 2.4 & 6.8 & 24.4 \\
\hline $482 \mathrm{~F}$ & 2 & 2.9 & 390 & 45 & 65 & 38 & 150 & 50 & 1.30 & 1.8 & 6.4 & 24.4 \\
\hline 483 & 21 & 3.9 & 900 & 46 & 120 & 120 & 220 & 52 & 1.58 & 1.4 & 7.5 & 25.3 \\
\hline 483B & 8 & 4.3 & 810 & 45 & 110 & 120 & 220 & 50 & 1.68 & 0.98 & 7.8 & 24.2 \\
\hline $483 C$ & 6 & 4.3 & 1000 & .45 & 120 & 135 & 195 & 52 & 1.55 & 1.2 & 7.8 & 24,4 \\
\hline $484 \mathrm{~A}$ & 7 & 3.3 & 890 & 40 & 75 & 97 & 180 & 52 & 1.30 & 2.8 & 6.8 & 23.2 \\
\hline 485 & 6 & 3.6 & 720 & 45 & 92 & 90 & 190 & 50 & 1.30 & 2.5 & 7.4 & 22.7 \\
\hline $485 \mathrm{~A}$ & 32 & 3.3 & 610 & 43 & 52 & 32 & 130 & 51 & 1.25 & 2.7 & 7.1 & 23.8 \\
\hline All sites & 104 & 3.5 & 700 & 43 & 81 & 73 & 170 & 51 & 1.38 & 2.1 & 7.2 & 24.1 \\
\hline \multicolumn{13}{|l|}{ Hemipelagics } \\
\hline silts & & 1.8 & 450 & - & 22 & 20 & 49 & 17 & 0.82 & 1.3 & 5.8 & 34.4 \\
\hline clays $^{\mathrm{a}}$ & & 6.6 & 730 & - & 83 & 96 & 245 & 53 & 1.9 & 0.64 & 9.9 & 22.7 \\
\hline \multicolumn{13}{|l|}{ Pacific } \\
\hline $\begin{array}{l}\text { pelagic } \\
\text { clayb }\end{array}$ & & 5.06 & 4800 & 101 & 211 & 323 & 160 & 68 & 1.76 & 0.66 & 9.34 & 25.0 \\
\hline \multirow{2}{*}{\multicolumn{2}{|c|}{$\begin{array}{l}\text { EPR } \\
\text { metalliferous } \\
\text { sediments }{ }^{\mathrm{c}}\end{array}$}} & & & & & & & 145 & & & & \\
\hline & & 17.5 & 45200 & 83 & 535 & 917 & 358 & 145 & 2.08 & 1.47 & 2.8 & 10.9 \\
\hline
\end{tabular}




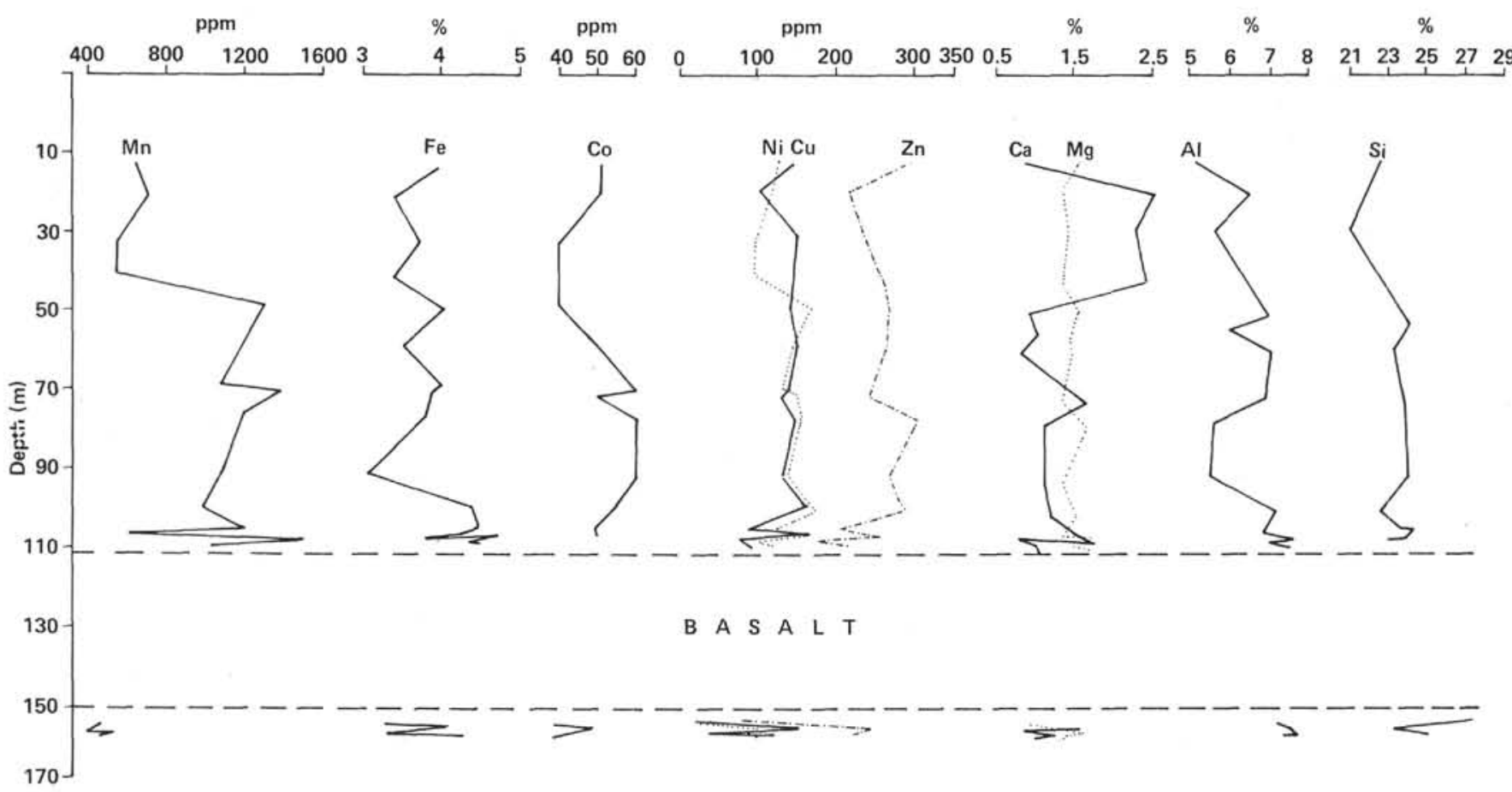

Figure 1. Variations in chemical composition with depth in Hole 483.

Table 2. Average partitioning of elements in Leg 65 sediments.

\begin{tabular}{|c|c|c|c|c|c|c|c|c|c|c|c|}
\hline Site & & $\begin{array}{c}\mathrm{Fe} \\
(\%)\end{array}$ & $\begin{array}{l}\mathrm{Mn} \\
(\%)\end{array}$ & $\begin{array}{l}\text { Co } \\
(\%)\end{array}$ & $\begin{array}{c}\mathrm{Ni} \\
(\%)\end{array}$ & $\begin{array}{c}\mathrm{Cu} \\
(\%)\end{array}$ & $\underset{(\%)}{\mathrm{Zn}}$ & $\begin{array}{l}\mathrm{Pb} \\
(\%)\end{array}$ & $\begin{array}{l}\mathrm{Mg} \\
(\%)\end{array}$ & $\begin{array}{c}\mathrm{Ca} \\
(\%)\end{array}$ & $\begin{array}{c}\mathrm{Al} \\
(\%)\end{array}$ \\
\hline \multirow[t]{4}{*}{482} & $\mathrm{HAC}$ & 7 & 32 & 13 & 13 & 14 & 19 & 15 & 13 & 66 & $<1$ \\
\hline & $\mathrm{Hy}$ & 10 & 9 & 7 & 15 & 17 & 20 & 12 & 4 & 21 & $<1$ \\
\hline & $\mathrm{HCl}$ & 48 & 42 & 20 & 10 & 16 & 40 & 1 & 71 & 3 & 40 \\
\hline & Res. & 35 & 17 & 60 & 62 & 53 & 21 & 71 & 13 & 10 & 59 \\
\hline \multirow[t]{4}{*}{483} & HAC & 3 & 26 & 24 & 32 & 8 & 16 & 18 & 16 & 48 & $<1$ \\
\hline & $\mathrm{Hy}$ & 4 & 6 & 4 & 10 & 27 & 23 & 30 & 4 & 15 & $<1$ \\
\hline & $\mathrm{HCl}$ & 72 & 54 & 39 & 30 & 36 & 49 & 4 & 73 & 17 & 49 \\
\hline & Res. & 21 & 14 & 33 & 28 & 28 & 12 & 47 & 7 & 20 & 50 \\
\hline \multirow[t]{4}{*}{484} & $\mathrm{HAC}$ & 3 & 33 & 13 & 18 & 3 & 12 & 15 & 23 & 73 & $<1$ \\
\hline & $\mathrm{Hy}$ & 3 & 3 & 14 & 4 & 10 & 15 & 28 & 4 & 15 & $<1$ \\
\hline & $\mathrm{HCl}$ & 77 & 54 & 46 & 29 & 49 & 63 & 9 & 60 & 8 & 48 \\
\hline & Res. & 17 & 10 & 27 & 49 & 38 & 10 & 47 & 14 & 5 & 51 \\
\hline \multirow[t]{4}{*}{485} & HAC & 9 & 36 & 17 & 20 & 3 & 12 & 19 & 19 & 66 & $<1$ \\
\hline & Hy & 5 & 6 & 4 & 10 & 12 & 15 & 13 & 3 & 13 & $<1$ \\
\hline & $\mathrm{HCl}$ & 62 & 47 & 35 & 16 & 37 & 54 & 6 & 67 & 9 & 44 \\
\hline & Res. & 24 & 11 & 44 & 54 & 48 & 19 & 62 & 10 & 12 & 55 \\
\hline Average & HAC & 6 & 32 & 14 & 21 & 7 & 15 & 17 & 18 & 63 & $<1$ \\
\hline & $\mathrm{Hy}$ & 5 & 6 & 7 & 10 & 16 & 18 & 21 & 4 & 16 & $<1$ \\
\hline \multirow[t]{2}{*}{ sites } & $\mathrm{HCl}$ & 65 & 49 & 35 & 19 & 35 & 52 & 5 & 67 & 9 & 45 \\
\hline & Res. & 24 & 13 & 41 & 50 & 42 & 15 & 57 & 11 & 12 & 54 \\
\hline
\end{tabular}

Note: $\mathrm{HAC}=$ acetic acid-soluble phase, $\mathrm{Hy}=$ hydroxylamine- $\mathrm{HCl}$-soluble phase, $\mathrm{HCl}=$ $\mathrm{HCl}$-soluble phase, Res. $=\mathrm{HCl}$-insoluble phase. Figures represent percentage of the respective totals of each element released by each selective leach.

amine- $\mathrm{HCl}$-soluble phase, indicating that the ferromanganese oxide contribution of $\mathrm{Mn}$ to these sediments is minimal, as would be expected in reducing sediments.

\section{Iron}

At Sites 483 and 484 more than $70 \%$ of the total Fe in the sediments is in the $\mathrm{HCl}$-soluble phase and thus is likely to occur within clay minerals. The rest of the iron (about $20 \%$ ) is virtually all in the $\mathrm{HCl}$-resistant phase and is therefore bound up in acid-resistant detrital minerals or pyrite. At Site 482 a rather greater proportion of the total $\mathrm{Fe}$ occurs in the $\mathrm{HCl}$-insoluble phase and significant amounts are also present in the acetic acid-soluble and hydroxylamine- $\mathrm{HCl}$-soluble fractions. Pyrite is more abundant at this site than at the others.
Partitioning of $\mathrm{Fe}$ in Site 485 sediments is intermediate between that in Site 482 sediments and that at Sites 483 and 484 .

\section{Nickel}

On the average, $50 \%$ of the total $\mathrm{Ni}$ in the sediments is present in the $\mathrm{HCl}$-insoluble phase, indicating that much of the $\mathrm{Ni}$ is bound up in resistant detrital minerals. At Site $482 \mathrm{HCl}$-insoluble Ni forms over $70 \%$ of the total, whereas at Site 483 only $30 \%$ is present in this form. At Sites 484 and 485 values between these are found. The detrital contribution of $\mathrm{Ni}$ in the Site 482 sediments is therefore higher than at the other sites, particularly Site 483 . As in the case of Mn, only a small percentage of the total $\mathrm{Ni}$ in the sediments occurs in the hydroxylamine- $\mathrm{HCl}$-soluble phase.

\section{Copper}

Copper shows a similar partitioning pattern to that of nickel; about $40 \%$ of the total $\mathrm{Cu}$ is in the $\mathrm{HCl}$-insoluble phase, with Site 482 showing the highest percentage of $\mathrm{Cu}$ in this phase $(53 \%)$, and Site 483 the lowest $(28 \%)$. Sites 484 and 485 show intermediate values. Proportionately more $\mathrm{Cu}$ than $\mathrm{Ni}$ is present in the $\mathrm{HCl}$-soluble phase, indicating a greater contribution of $\mathrm{Cu}$ than $\mathrm{Ni}$ in the clay mineral component of the sediments. Almost $30 \%$ of the total Cu at Site 483 occurs in the hydroxylamine- $\mathrm{HCl}$-soluble phase, compared with an overall average of $15 \%$; this indicates a greater authigenic contribution of $\mathrm{Cu}$ to the sediments at Site 483 than at the other sites.

\section{Cobalt}

The partitioning pattern for $\mathrm{Co}$ is similar to those for $\mathrm{Ni}$ and $\mathrm{Cu}$, with the largest percentage of $\mathrm{Co}$ being 
present in the $\mathrm{HCl}$-resistant phase and much of the rest being present in the $\mathrm{HCl}$-soluble phase, indicating association with resistant detrital minerals and clay minerals, respectively. Again, the sediments from Site 482 show the highest detrital contribution, whereas those from Sites 483 and 484 show the lowest contribution and those from Site 485 display an intermediate value.

\section{Lead}

Most of the $\mathrm{Pb}$ at all four sites is present in the $\mathrm{HCl}-$ insoluble phase $(57 \%)$ and, again, more $\mathrm{Pb}$ is present in this phase at Site $482(71 \%)$ than at Sites $485(62 \%), 483$ $(47 \%$ ), and 484 (also $47 \%$ ). At Sites 483 and 484 much of the rest of the $\mathrm{Pb}$ is present in the hydroxylamine$\mathrm{HCl}$-soluble phase, but at Sites 482 and 485 the remaining $\mathrm{Pb}$ is distributed more evenly between this phase and the acetic acid-soluble phase. Virtually no $\mathrm{Pb}$ occurs in the $\mathrm{HCl}$-soluble phase at any site.

\section{Zinc}

Zinc shows a slightly different partitioning pattern from that of $\mathrm{Co}, \mathrm{Ni}, \mathrm{Cu}$, and $\mathrm{Pb}$. Most of the $\mathrm{Zn}$ is present in the $\mathrm{HCl}$-soluble phase, associated with clay minerals, and there is little variation in the partitioning of $\mathrm{Zn}$ between sites. The remaining $\mathrm{Zn}$ is partitioned roughly equally between the remaining three phases. There is a slightly larger percentage of $\mathrm{HCl}$-insoluble $\mathrm{Zn}$ at Sites 482 and 485 (about 20\%) compared to the amounts in sediments from Sites 483 and 484 (about $10 \%$ ).

\section{Calcium}

The partitioning pattern for $\mathrm{Ca}$ is strongly influenced by the $\mathrm{CaCO}_{3}$ content of the sediments. Between $50 \%$ and $75 \%$ of the total $\mathrm{Ca}$ is present in the acetic acid-soluble phase at all sites; sediments with the highest bulk $\mathrm{Ca}$ content contain the highest percentage of acetic acidsoluble $\mathrm{Ca}$ and vice versa. Thus, Site 484 sediments contain the highest percentage of acetic acid-soluble $\mathrm{Ca}$ whereas $\mathrm{Ca}$ is lowest in this phase in the Site 483 sediments. The $\mathrm{Ca}$ not present in the acetic acid-soluble phase is partitioned irregularly between the other three phases, with no clear trends visible between the sites.

\section{Magnesium}

Magnesium shows a similar partitioning pattern at all four sites. On the average almost $70 \%$ of the total $\mathrm{Mg}$ is present in the $\mathrm{HCl}$-soluble phase, indicating a strong association with clay minerals. Just under $20 \%$ of the total $\mathrm{Mg}$ is acetic acid-soluble. This $\mathrm{Mg}$ is probably associated with the carbonate phase since it is more abundant in samples with a higher $\mathrm{Ca}$ content.

\footnotetext{
Aluminium

Aluminium is partitioned exclusively between the $\mathrm{HCl}$-soluble and $\mathrm{HCl}$-insoluble phases at all four sites. At Sites 483 and 484 the proportion of $\mathrm{Al}$ in each of these phases is approximately $50 \%$, but at Site 485 , and more particularly at Site 482 , more $\mathrm{Al}$ is present in the $\mathrm{HCl}$-insoluble phase, indicating an increase in the proportion of resistant $\mathrm{Al}$-silicate material.
}

\section{DISCUSSION}

The iron and trace metal enrichment seen in sediments immediately overlying the oceanic crust in many localities on the flanks of the East Pacific Rise (von der Borch and Rex, 1970; Cronan et al., 1972) has not been found at Sites 482 through 485 . The values of $\mathrm{Fe}, \mathrm{Mn}$, $\mathrm{Ni}, \mathrm{Cu}, \mathrm{Zn}$, and $\mathrm{Pb}$ observed are much lower and the $\mathrm{Al}$ much higher than in East Pacific Rise metalliferous sediments. However, the sedimentation rates at Leg 65 sites are 60-625 m/m.y. (Lewis et al., 1979), one to two orders of magnitude higher than those in ridge flank areas in the Pacific where metalliferous sediments have been found. Any authigenic and hydrothermal inputs to the sediments are therefore likely to have been considerably more diluted by detrital material than elsewhere on the East Pacific Rise. In this respect, it is interesting to note that the sediments in the three holes drilled at Site 483 , where sediment accumulation rates are lowest, contain the highest levels of $\mathrm{Mn}, \mathrm{Fe}, \mathrm{Ni}, \mathrm{Cu}$, and $\mathrm{Zn}$. However, the overall values of these elements are still typical of normal hemipelagic sediments. Layers of finergrained sediment of more truly pelagic nature occur in all the holes sampled and must indicate periods of slower sedimentation. The samples highest in $\mathrm{Mn}, \mathrm{Ni}$, $\mathrm{Cu}$, and $\mathrm{Zn}$, however, were not confined to these layers but also occurred in predominantly terrigenous silty clays. At Sites 482,483 , and 485 , sediments were also recovered beneath the uppermost basalt flow (i.e., the top of the acoustic basement); these were sampled, but in all cases showed no metal enrichment, being generally similar in composition to the sediments above the basement.

The basal metalliferous sediments seen elsewhere on the flanks of the East Pacific Rise contain $\mathrm{Fe}$ as an oxide phase (von der Borch and Rex, 1970; Dymond et al., 1973). However, at $21^{\circ} \mathrm{N}$ hydrothermally derived sulfides of $\mathrm{Fe}, \mathrm{Cu}$, and $\mathrm{Zn}$ are forming on the seafloor (Francheteau et al., 1979). These sulfides occur as very localized deposits and are being precipitated before any appreciable sediment cover has accumulated. It is possible that ancient analogs of these deposits might exist in the area but that none was drilled on Leg 65 . Although pyrite was reported in the basal and near-basal sediments at all sites (see site chapters, this volume), it is probably largely diagenetic in origin, and the amounts are generally too small to increase significantly the total $\mathrm{Fe}$ concentration in the sediments. However, the amounts of pyrite in the sediments at Site 482 show an increase immediately above the basement and, as will be mentioned, some of this may be hydrothermal.

About three-quarters of the totals of $\mathrm{Co}, \mathrm{Ni}$, and $\mathrm{Cu}$ and $65 \%$ of the totals of $\mathrm{Mn}, \mathrm{Zn}$, and $\mathrm{Pb}$ in the sediments occur in the $\mathrm{HCl}$-soluble and. $\mathrm{HCl}$-insoluble phases and are therefore largely of detrital origin. Since about $90 \%$ of the total $\mathrm{Fe}$ also occurs in these two phases, detrital sources may be the major supplier of this element as well. Any Fe associated with pyrite in the sediments will, however, be present in the $\mathrm{HCl}$-resistant fraction and will be indistinguishable, using the techniques previously described, from the $\mathrm{HCl}$-insoluble $\mathrm{Fe}$ 
in silicate material. The average total $\mathrm{Fe}, \mathrm{Cu}$, and $\mathrm{Zn}$ contents of the sediments are typical of normal hemipelagic sediments, and if any hydrothermally derived sulfides are present in the sediments analyzed, their amounts must be very small. It is interesting to note, as mentioned, that several samples taken near the sediment/basalt contact at Site 482 show an increase in $\mathrm{HCl}$-resistant $\mathrm{Fe}$ and $\mathrm{Cu}$ and a smaller increase in $\mathrm{HCl}$ resistant $\mathrm{Zn}$ relative to the sediments previously described. This may indicate the presence of very small amounts of hydrothermal sulfide material in these sediments.

At all sites, only small percentages of the total Mn, $\mathrm{Co}, \mathrm{Ni}, \mathrm{Cu}, \mathrm{Zn}$, and $\mathrm{Pb}$ are present in the biogenic and authigenic phases released by acetic acid and hydroxylamine- $\mathrm{HCl}$. The slightly larger percentages of some of these metals released by such attacks from the Site 483 sediments indicate a slight increase in the biogenic and authigenic contribution to these sediments relative to the other sites, a conclusion entirely consistent with the slower accumulation rate and more pelagic nature of the sediments at this site. The low concentrations of hydroxylamine- $\mathrm{HCl}$-soluble $\mathrm{Mn}$ in the Leg 65 sediments is consistent with their predominantly reducing nature and the consequent absence of $\mathrm{Mn}$ oxides.

Comparison of the partitioning data for the Leg 65 sediments with those of previously analyzed Pacific and Atlantic DSDP sediments (Cronan, 1976; Horowitz and Cronan, 1976; Varnavas, 1979) shows important differences. Sediments from the western flank of the East Pacific Rise (Cronan, 1976) and from the ridge crest area at $9^{\circ} \mathrm{S}$ (Varnavas, 1979) are higher in total Mn, Fe, $\mathrm{Co}, \mathrm{Ni}, \mathrm{Cu}, \mathrm{Zn}$, and $\mathrm{Pb}$ content and contain little, if any, of these elements in the $\mathrm{HCl}$-insoluble phase. They contain much more hydroxylamine- $\mathrm{HCl}$-soluble $\mathrm{Mn}$, $\mathrm{Fe}, \mathrm{Ni}, \mathrm{Cu}$, and $\mathrm{Pb}$ than the Leg 65 sediments, indicating the presence in them of substantial amounts of reducible oxide phases. Basal and nonbasal sediments from DSDP Site 118 at the eastern margin of the Atlantic (Horowitz and Cronan, 1976) show more similarity with the Leg 65 sediments, the partitioning patterns of $\mathrm{Fe}, \mathrm{Cu}, \mathrm{Pb}$, and $\mathrm{Al}$ being quite similar in both sample groups. The Atlantic sediments are higher in total $\mathrm{Mn}$, however, much of which is present in the hydroxylamine- $\mathrm{HCl}$-soluble phase, indicating the presence of reducible oxides. In addition, the detrital, $\mathrm{HCl}$-insoluble component of $\mathrm{Mn}, \mathrm{Cu}, \mathrm{Ni}$, and $\mathrm{Pb}$ is lower than in the Leg 65 sediments.

Horowitz and Cronan (1976) suggested that the comparatively low levels of $\mathrm{Mn}, \mathrm{Ni}, \mathrm{Cu}, \mathrm{Zn}$, and $\mathrm{Pb}$ in basal sediments from DSDP Hole 9A in the western Atlantic might be due to postdepositional migration of these elements and their reprecipitation higher up in the sedimentary column upon encountering more oxidizing conditions. In view of the reducing nature of much of the Leg 65 sediments studied, postdepositional migration of some elements may also have occurred in these sediments, leading to their removal from basal and nearbasal sediments and their migration upward. Such a process however, would not have affected any hydrothermal sulfide phases, but only authigenic or hydrothermal oxide phases.
The fact that no real chemical evidence for hydrothermal activity was found in the Leg 65 sediments does not necessarily mean that no hydrothermal processes have operated in the area drilled by Leg 65 . Indeed, Duennebier and Blackinton (1980) have shown that hydrothermal circulation may still be occurring in the basement below Site 482 . Since the localized occurrence of the sulfides on the East Pacific Rise at $21^{\circ} \mathrm{N}$ indicates that the chance of encountering a similar deposit in a DSDP core is rather low, it may be that they are there but have not been sampled.

\section{CONCLUSIONS}

1. The Leg 65 sediments in general display bulk chemical compositions typical of normal hemipelagic sediments from the Pacific Ocean and elsewhere.

2. The bulk $\mathrm{Mn}, \mathrm{Fe}, \mathrm{Al}$, and trace metal contents of the sediments, the lack of reducible oxide phases, and the absence of appreciable sulfides in the samples distinguish them from basal and nonbasal metalliferous sediments and other hydrothermal deposits found elsewhere on the East Pacific Rise crest and flanks.

3. The partitioning patterns of $\mathrm{Mn}, \mathrm{Fe}, \mathrm{Al}$, and the trace metals suggest that there has been no major authigenic or hydrothermal contribution of these elements to the sediments and that for the most part these elements are incorporated in the sediments in detrital phases. In this respect they show some similarity to basal and nonbasal sediments from DSDP Site 118, a marginal Atlantic Ocean site.

4. The partitioning patterns of $\mathrm{Mn}, \mathrm{Fe}, \mathrm{Al}$, and trace metals also show that detrital phases played a more important role in supplying these elements to the sediments at Site 482 and 485 than to sediments at Sites 483 and 484. This is compatible with the relative geographic locations of these holes and with calculated sedimentation rates.

5 . Whereas the existence of hydrothermal processes associated with the spreading ridge at $23^{\circ} \mathrm{N}$ cannot be ruled out, it seems likely that rapidly accumulating sediments may have greatly diluted any hydrothermal supply of metals to the seafloor.

\section{REFERENCES}

Boström, K., Joensuu, O., Valdes, S., et al., 1976. Geochemistry and origin of east Pacific sediments sampled during DSDP Leg 34. In Yeats, R. S., Hart, S. R., et al., Init. Repts. DSDP, 34: Washington (U.S. Govt. Printing Office), 559-574.

Boström, K., and Peterson, M. N. A., 1966. Precipitates from hydrothermal exhalations on the East Pacific Rise. Econ. Geol., 61:1258-1265.

Boström, K., Peterson, M. N. A., Joensuu, O., et al., 1969. Aluminium-poor ferromanganoan sediments on active ocean ridges. $J$. Geophys. Res., 74:3261-3270.

Calvert, S. E., 1976. The mineralogy and geochemistry of near-shore sediments. In Riley, J. P., and Skirrow, R. (Eds.), Chemical Oceanography (Vol. 6): New York (Academic Press), 187-280.

Chester, R., and Hughes, M. J., 1967. A chemical technique for the separation of ferromanganese minerals, carbonate minerals and adsorbed trace elements from pelagic sediments. Chem. Geol., 2:249-262

Cronan, D. S., 1969. Average abundances of $\mathrm{Mn}, \mathrm{Fe}, \mathrm{Ni}, \mathrm{Co}, \mathrm{Cu}$ $\mathrm{Pb}, \mathrm{Mo}, \mathrm{V}, \mathrm{Cr}, \mathrm{Ti}$, and $\mathrm{P}$ in Pacific pelagic clays. Geochim. Cosmochim. Acta, 33:1562-1565.

1973. Basal ferruginous sediments cored during Leg 16, Deep Sea Drilling Project. In van Andel, Tj. H., Heath, G. R., et 
al., Init. Repts. DSDP, 16: Washington (U.S. Govt Printing Office), 601-604

1976. Basal metalliferous sediments from the eastern Pacific. Geol. Soc. Am. Bull., 87:928-934.

Cronan, D. S., van Andel, Tj. H., Heath, G. R., et al., 1972. Ironrich basal sediments from the eastern Equatorial Pacific: Leg 16 Deep Sea Drilling Project. Science, 175:61-63.

Duennebier, F., and Blackinton, G., 1980. A man-made hot spring on the ocean floor. Nature, $284: 338-340$.

Dymond, J., Corliss, J. B., Heath, G. R., et al., 1973. Origin of metalliferous sediments from the Pacific Ocean. Geol. Soc. Am. Bull., 84:3355-3372.

Emiliani, C., 1955. The mineralogical and chemical composition of the tests of certain pelagic foraminifera. Micropaleontology, $1: 377-380$.

Francheteau, J., Needham, H. D., Choukroune, P., et al., 1979. Massive deep-sea sulphide ore deposits discovered on the East Pacific Rise. Nature, 277:523-528.

Horder, M. F., 1979. Geochemical investigations of deep-sea sediments from the Indian Ocean [Unpubl. Ph.D. thesis]. Univ. of Lond.
Horowitz, A., and Cronan, D. S., 1976. The geochemistry of basal sediments from the North Atlantic Ocean. Mar. Geol., 20: 205-228.

Lewis, B. T. R., Robinson, P., Benson, R. N., et al., 1979. Leg 65 drills into young ocean crust. Geotimes, 24(8):16-18.

Sayles, F., and Bischoff, J.L., 1973. Ferromanganoan sediments in the equatorial East Pacific. Earth Planet Sci. Lett., 19:330-336.

Turekian, K. K., and Wedepohl, K. H., 1961. Distribution of the elements in some major units of the earth's crust. Geol. Soc. Am. Bull., 72:175-192.

Varnavas, S. P., 1979. Geochemical investigations on sediments from the eastern Pacific [Ph.D. thesis]. Univ. of London.

von der Borch, C. C., and Rex, R. W., 1970. Amorphous iron-oxide precipitates cored during Leg 5, Deep Sea Drilling Project. In McManus, D. A., Burns, R. E., et al., Init. Repts. DSDP, 5: Washington (U.S. Govt. Printing Office), 541-544.

Wright, P. L., 1972. The geochemistry of recent sediments of the Barents Sea [Ph.D. thesis]. University of Edinburgh. 